\title{
Kajian Matriks Bobot Lokasi Model Space Time Autoregresi (STAR)
}

\author{
Emah Suryamah, Budi Nurani Ruchjana, Khafsah Joebaedi \\ Jurusan Matematika, Fakultas MIPA, Universitas Padjadjaran \\ Jl. Raya Bandung Sumedang Km 21 Jainangor Sumedang 45363 \\ e-mail: emah_suryamah@yahoo.com
}

\begin{abstract}
ABSTRAK
Model STAR (Space Time Autoregresi) merupakan pengembangan dari model deret waktu univariat AR (Autoregresi), menjadi model kombinasi lokasi dan waktu. Keterkaitan antar lokasi penelitian pada model STAR dinyatakan dengan matriks bobot W yang merupakan matriks bujur sangkar dengan entri-entri berupa bobot antara dua lokasi yang bersesuaian. Dalam makalah ini dibahas tiga macam matriks bobot untuk model STAR(1;1), yaitu: matriks bobot seragam, matriks bobot seperjarak kuadrat dan matriks bobot spasial, menentukan dan menggunakan matriks bobot tersebut pada data simulasi, membandingkan serta memilih mana yang lebih baik diantara ketiganya dengan kriteria jumlah kuadrat galat yang paling minimum. Taksiran model STAR(1;1) dengan tiga macam bobot menghasilkan jumlah kuadrat galat yang minimum untuk model dengan matriks bobot spasial. Hal ini berarti bahwa bobot spasial memberikan taksiran parameter model $\operatorname{STAR}(1,1)$ yang lebih baik dibandingkan penggunaan matriks bobot seragam dan seperjarak kuadrat.
\end{abstract}

Kata kunci: Matriks bobot, model STAR, autoregresi

\section{ABSTRACT}

STAR (Space Time Autoregressive) model is a development of univariate time series model AR (Autoregressive), became a combination model of location and time. Relationship between locations in the STAR model represented by W weights matrix is a square matrix that has entries in the form of weights between two corresponding locations. This paper discusses three kinds of weighting matrix for STAR(1,1) model, namely: uniform weighting matrix, inverse distance squares weight matrix and spatial weights matrix, how to define it and use it on simulated data, comparing and choosing which one is better among the three weight matrices using criteria the minimum of sum squared error. Estimated STAR models $(1,1)$ with three kinds of weights produces the minimum of sum squares error for spatial weights. This means that the spatial weights gives more better result for estimation of STAR(1,1) model comparing with uniform and inverse distance squares weights..

Keywords: weights matrix, STAR model, autoregressive

\section{Pendahuluan}

Dalam kehidupan sehari-hari seringkali ditemukan masalah yang berkaitan dengan waktu, contohnya masalah curah hujan, produksi minyak bumi, fluktuasi nilai tukar rupiah per hari dan lain-lain. Data yang berkaitan dengan waktu dinamakan data deret waktu atau time series. Salah satu model yang digunakan dalam model deret waktu adalah model univariat yang 
disebut dengan model Autoregresi dan disingkat dengan AR. Model AR menyatakan suatu observasi waktu sekarang dipengaruhi oleh observasi waktu sebelumnya.

Data deret waktu berkembang menjadi data lokasi waktu (space time). Data pengamatan yang tergantung pada lokasi dinamakan data spasial. Fungsi autokovariansi dalam proses deret waktu maupun proses spasial merupakan alat penting untuk menggambarkan struktur ketergantungan atau korelasi dari waktu. Banyak pengamatan yang dapat diamati dan dianalisis berdasarkan waktu dan lokasi, misalnya Model Space Time Autoregresi (STAR) yang dikaji oleh Pfeifer-Deutsch [5]. Model STAR(1;1) mempunyai karakteristik adanya ketergantungan linier dalam lag time maupun lag spasial.

Model STAR $(1 ; 1)$ sesuai dengan fenomena bahwa pengamatan waktu sekarang di lokasi tertentu dipengaruhi oleh pengamatan satu waktu sebelumnya di lokasi tersebut dan lokasi di sekitarnya yang berada dalam satu kelompok (Pfeifer-Deutsch, [5]). Model STAR(1,1) mengasumsikan fenomena deret waktu dengan karakteristik lokasi seragam (homogen), sehingga parameter autoregresi maupun parameter deret waktu konstan untuk semua lokasi. Salah satu karakteristik model deret waktu adalah adanya korelasi dalam waktu maupun lokasi. Korelasi antar lokasi direpresentasikan melalui matriks bobot W. Matriks W merupakan matriks bujur sangkar yang memiliki entri berupa bobot antara dua lokasi yang bersesuaian.

Dalam makalah ini dibahas kajian tentang matriks bobot dan bagaimana cara menentukan matriks bobot pada model STAR $(1,1)$. Bentuk matriks bobot yang dipelajari terbatas pada bentuk bobot seragam, bobot seperjarak kuadrat dan bobot spasial. Kajian matriks bobot model STAR(1;1) dapat dijelaskan melalui taksiran parameter model. Selanjutnya matriks bobot yang diperoleh diterapkan pada data simulasi untuk memperoleh taksiran parameter model STAR(1;1). Taksiran model STAR(1,1) dengan berbagai matriks bobot dibandingkan melalui jumlah kuadrat galat. Model STAR(1,1) dengan jumlah kuadrat galat yang minimum merupakan model terbaik.

\section{Kajian Pustaka}

\subsection{Data Deret Waktu}

Data deret waktu adalah himpunan pengamatan yang dibangun berurutan dalam waktu. Notasi $Z(t)$ menyatakan variabel acak pada waktu $t$. Waktu $t$ bisa merupakan tahun, bulan, hari, jam atau waktu lainnya tergantung situasi [2]. Model deret waktu stasioner terdiri atas model Autoregresi (AR) dan model Moving Average (MA). Model Autoregresi orde $p$ adalah suatu model dimana hasil pengamatan waktu ke- $t$ dinyatakan sebagai 
kombinasi linear dari hasil pangamatan waktu-waktu sebelumnya, yaitu berbentuk:

$$
Z(t)=\phi(1) Z(t-1)+\phi(2) Z(t-2)+\ldots+\phi(\mathrm{q}) Z(t-p)+e(t)
$$

Adapun yang disebut dengan model Moving Average orde $q$ adalah model dimana pengamatan pada waktu ke- $t$ dinyatakan sebagai kombinasi linear dari galat-galat $e(t), e(t-1), e(t-2), \ldots, e(t-q)$, yaitu:

$$
Z(t)=e(t)-\theta(1) e(t-1)-\theta(2) e(t-2)-\quad \ldots \quad-\theta(q) e(t-q)
$$

dengan $\{e(t)\}$ adalah galat berdistribusi identik normal, mean nol dan variansi konstan, dituliskan:

$$
\begin{array}{ll}
\text { Mean E }(e(t)) & =\mu, \text { konstan, (biasanya diasumsikan bernilai nol) } \\
\operatorname{Var}(e(t)) & =\sigma^{2} \text { konstan, dan } \\
\gamma_{\mathrm{k}} & =\operatorname{Cov}(e(t), e(t+k))=0 \text { untuk semua } k \neq 0
\end{array}
$$

\subsection{Model Space Time Autoregresi Orde 1, STAR $(1,1)$} berikut:

Persamaan model STAR $(1 ; 1)$ dari Peifer [5] dapat dinyatakan sebagai

dengan

$$
\boldsymbol{Z}(t)=\phi_{10} \boldsymbol{Z}(t-1)+\phi_{11} \mathbf{W} \boldsymbol{Z}(t-1)+\boldsymbol{e}(t)
$$

$$
\begin{array}{ll}
Z(t) & : \text { vektor pengamatan }(N \times 1) \text { dari } N \text { lokasi pada waktu } t \\
\mathbf{W} & : \text { matriks bobot }(N \times N) \text { pada lag spasial } 1 \\
t & : \text { waktu pengamatan }(1,2,3, \ldots, T) \\
\phi_{10} & : \text { parameter model pada lag spasial } 0 \text { dan lag waktu } 1 \\
\phi_{11} & : \text { parameter model pada lag spasial } 1 \text { dan lag waktu } 1 \\
& \text { dengan } e(t) \sim N\left(0, \sigma^{2}\right)
\end{array}
$$

Model STAR $(1,1)$ menjelaskan pengaruh pengamatan deret waktu maupun pengaruh pengamatan lokasi-lokasi lain di sekitar suatu lokasi tertentu secara simultan melalui parameter autoregresi dan parameter lokasi waktu.

\subsection{Sifat Matriks Bobot}

Matriks bobot $\mathbf{W}$ bisa bersifat simetris atau tidak simetris, tergantung pada bentuk bobot yang dipilih. Matriks bobot merupakan matriks bujur sangkar ukuran $(N \times N)$ dan memiliki beberapa sifat, yaitu:

1. Bobot dipilih yang nilainya positif, $w_{i j}>0$.

2. Jumlah bobot untuk setiap lokasi adalah1

$$
\sum_{j=1}^{N} w_{i j}=1, \forall i \text { dan } \sum_{i=1}^{N} \sum_{j=1}^{N} w_{i j}=N
$$

3. Diagonal matriks bobot $\mathbf{W}$ adalah nol, karena untuk suatu lokasi dianggap tidak ada jarak dengan dirinya sendiri, sehingga $\operatorname{tr}[w i j]=$ $\operatorname{tr}[w j i]=0$, dimana trace matriks adalah jumlah elemen diagonal. 
Dengan menggunakan entri pada matriks bobot, persamaan (2.3) untuk empat lokasi dapat dituliskan sebagai berikut:

$$
\begin{aligned}
& Z_{1}(t)=Z_{1}(t-1) \phi_{10}+w_{12} Z_{2}(t-1) \phi_{11}+w_{13} Z_{3}(t-1) \phi_{11}+w_{14} Z_{4}(t-1) \phi_{11}+e_{1}(t) \\
& Z_{2}(t)=Z_{2}(t-1) \phi_{10}+w_{21} Z_{1}(t-1) \phi_{11}+w_{23} Z_{3}(t-1) \phi_{11}+w_{24} Z_{4}(t-1) \phi_{11}+e_{2}(t) \\
& Z_{3}(t)=Z_{3}(t-1) \phi_{10}+w_{31} Z_{1}(t-1) \phi_{11}+w_{32} Z_{2}(t-1) \phi_{11}+w_{34} Z_{3}(t-1) \phi_{11}+e_{3}(t) \\
& Z_{4}(t)=Z_{4}(t-1) \phi_{10}+w_{41} Z_{1}(t-1) \phi_{11}+w_{42} Z_{2}(t-1) \phi_{11}+w_{43} Z_{3}(t-1) \phi_{11}+e_{4}(t)
\end{aligned}
$$

\subsection{Jarak Euclidean}

Definisi: Jika $P, Q$ dua titik di $R^{2}$, maka jarak $P$ dan $Q$ adalah:

$$
d(P, Q)=|Q-P|
$$

Misalkan $P\left(x_{1}, y_{1}\right)$ dan $Q\left(x_{2}, y_{2}\right) € R^{2}$ dan vektor yang terbentuk dari titik $P$ dan $Q$ adalah vektor $\overline{P Q}:=\left(x_{2}-x_{1}, y_{2}-y_{1}\right)=\left(x_{1}, y_{2}\right)-\left(x_{1}, y_{1}\right)=(Q-P)$, maka dapat dikatakan bahwa panjang $P Q$ adalah jarak $P$ dan $Q$ sehingga [4]:

$$
\begin{aligned}
& d(P, Q)=|Q-P| \\
& =\sqrt{(Q-P)^{2}} \\
& =\sqrt{\left(\left(x_{2}, y_{2}\right)-\left(x_{1}, y_{1}\right)\right)^{2}} \\
& =\sqrt{\left(x_{2}-x_{1}\right)^{2}+\left(y_{2}-y_{1}\right)^{2}}
\end{aligned}
$$

Definisi pada persamaan (2.5) ini digunakan untuk menghitung jarak antara dua lokasi ketika menentukan matriks seperjarak kuadrat dan matriks bobot spasial.

\section{Hasil dan Pembahasan}

\subsection{Bobot Seragam (Uniform Weights)}

Bobot seragam berdasarkan Metode Koding Besag dalam Ruchjana [3] merupakan bentuk paling sederhana dan mudah ditentukan untuk lokasilokasi dalam sistem lattice teratur di $\mathrm{R}^{2}$. Pengelompokan lokasi dilakukan berdasarkan urutan jarak antara dua lokasi. Dalam sistem teratur bobot seragam dapat ditentukan berdasarkan grid atau lingkaran. Dalam penelitian ini matriks bobot seragam dinotasikan $\mathbf{W}_{\mathbf{u}}$.

Bobot ditentukan susuai dengan ukuran anggota dalam suatu kelompok lokasi. Bobot seragam dinyatakan :

$$
w_{i j}=\left\{\begin{array}{l}
\frac{1}{m^{l}}, \text {,jika lokasi } i \text { dan lokasi } j \text { merupakan tetangga terdekat lag pada lokasi } l \\
0 .
\end{array}\right.
$$

dengan $m_{\mathrm{ij}}$ adalah banyaknya tetangga terdekat dari lokasi $i$ pada lag spasial $l=1$. Untuk posisi 4 lokasi pada grid teratur seperti gambar berikut: 


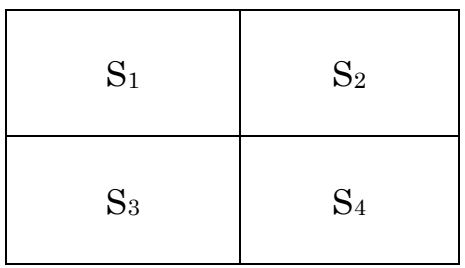

Gambar 3.1 posisi 4 Lokasi pada Grid Teratur

Berdasarkan Gambar 3.1 diperoleh matriks bobot seragam sebagai berikut :

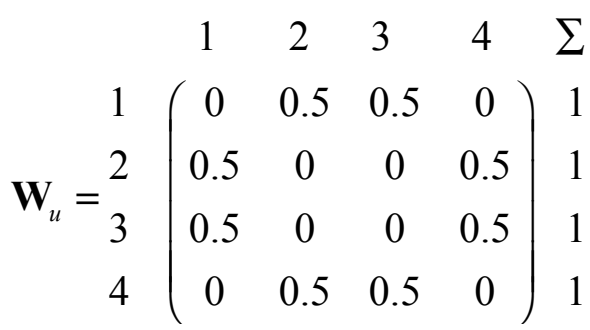

\subsection{Bobot Seperjarak Kuadrat (Inverse Distance Squares Weights)}

Bobot ditentukan oleh jarak lokasi di sekitar suatu lokasi tertentu.

$$
a_{i j}=\frac{1}{d_{i j}^{2}} \quad, \sum_{j=1}^{N} a_{i j}=1
$$

$d_{\text {ij }}$ adalah jarak antara lokasi $i$ dan $j$. Untuk 4 lokasi pada grid teratur seperti Gambar 3.1 diperoleh matriks jarak dari titik tengah setiap lokasi (dalam satuan jarak):

$$
M=\left(\begin{array}{cccc}
0 & 1 & 1 & \sqrt{2} \\
1 & 0 & \sqrt{2} & 1 \\
1 & \sqrt{2} & 0 & 1 \\
\sqrt{2} & 1 & 1 & 0
\end{array}\right)
$$

Bobot seperjarak kuadrat adalah:

$$
K=\left(\begin{array}{cccc}
0 & 1 & 1 & \frac{1}{2} \\
1 & 0 & \frac{1}{2} & 1 \\
1 & \frac{1}{2} & 0 & 1 \\
\frac{1}{2} & 1 & 1 & 0
\end{array}\right)
$$

Berhubung matriks ini belum memenuhi sifat-sifat matriks bobot maka setiap elemen dibagi dengan jumlah semua elemen pada baris yang bersesuaian, dirumuskan: 


$$
w_{i j}=\frac{\left\{\frac{1}{d_{i j}^{2}}\right\}}{\sum_{j=1}^{4}\left\{\frac{1}{d_{i j}^{2}}\right\}} \forall \mathrm{i}=1,2,3,4
$$

$w_{i j}$ adalah bobot antara lokasi $i$ dan $j, d_{i j}$ adalah jarak antara lokasi $i$ dan $j$. Matriks bobot seperjarak kuadrat untuk 4 lokasi adalah:

$$
\mathbf{W}=\left(\begin{array}{cccc}
0 & 0.4 & 0.4 & 0.2 \\
0.4 & 0 & 0.2 & 0.4 \\
0.4 & 0.2 & 0 & 0.4 \\
0.2 & 0.4 & 0.4 & 0
\end{array}\right)
$$

\subsection{Bobot Spasial (Spatial Weights)}

Bobot spasial diusulkan untuk menentukan bobot melalui korelasi spasial. Korelasi spasial dapat dihitung melalui semivariogram, yaitu diagram selisih variansi pengamatan dalam jarak dan arah tertentu. Jika semivariogram hanya ditentukan berdasarkan jarak, maka bersifat isotropik. Untuk menentukan bobot spasial dapat dipilih variabel-variabel spasial yang mempengaruhi proses acak dalam model space time. Misalnya untuk pengamatan space time berupa produksi minyak bmi per bulan dai beberapa lokasi sumur dapat dipilih variabel porositas sebagai bobot spasial. Bobot spasial berdasarkan semivariogram dapat ditentukan berdasarkan persamaan berikut ini (Ruchjana [3]):

$$
\begin{aligned}
& W_{s}\left(h_{i j}\right)= \begin{cases}\frac{a_{i j}}{A_{i j}} & i \neq j \\
0 & i=j\end{cases} \\
& a_{i j}=\left\{\begin{array}{cc}
{\left[1+\gamma\left(h_{i j}\right)\right]^{-1}} & , i \neq j \\
0 & i=j
\end{array}\right. \\
& A_{i j}=\sum_{j \neq 1}^{N} a_{i j} \\
& \gamma(h)=\frac{1}{2 N(h)_{\left\{\left(s_{i}, s_{j}\right): d\left(s_{i}, s_{j}\right) \leq h\right\}}}\left[Y\left(s_{i}\right)-Y\left(s_{j}\right)\right]^{2}
\end{aligned}
$$

dengan $N(h)$ adalah banyaknya pasangan data berjarak kurang dari $h$ dengan $d(s i, s j) \leq h, d$ menyatakan jarak Euclides antara dua lokasi (Cressie, 1993 dalam Ruchjana [3]) Selanjutnya persamaan ini dapat dipilih untuk mendefinisikan bobot spasial. Matriks bobot spasial distandarisasi $\mathbf{W}_{s}$ untuk 4 lokasi dinyatakan dengan persamaan (3.9). 


$$
\mathrm{W}_{s}=\left(\begin{array}{cccc}
0 & w_{s}\left(h_{12}\right) & w_{s}\left(h_{13}\right) & w_{s}\left(h_{14}\right) \\
w_{s}\left(h_{21}\right) & 0 & w_{s}\left(h_{23}\right) & w_{s}\left(h_{24}\right) \\
w_{s}\left(h_{31}\right) & w_{s}\left(h_{32}\right) & 0 & w_{s}\left(h_{34}\right) \\
w_{s}\left(h_{41}\right) & w_{s}\left(h_{42}\right) & w_{s}\left(h_{43}\right) & 0
\end{array}\right)
$$

\subsection{Studi Simulasi untuk Studi Kasus Penerapan Matriks Bobot}

Dalam penelitian ini untuk studi kasus penerapan model $\operatorname{STAR}(1,1)$ menggunakan tiga matriks bobot digunakan data simulasi. Untuk menentukan bobot seragam dan seperjarak kuadrat digunakan persamaan (3.2) dan (3.5) dengan posisi 4 lokasi pada grid teratur seperti Gambar 3.1. Sedangkan untuk bobot spasial menggunakan semivariogram, digunakan contoh data pada grid teratur 2D dari Amstrong [1] sebagai berikut:

Tabel 3.1 Data Grid Teratur 2D (64 lokasi pada setiap grid 1x1 satuan jarak)

\begin{tabular}{|r|r|r|r|r|r|r|r|}
\hline 26 & 22 & 19 & 14 & 16 & 19 & 16 & 14 \\
\hline 23 & 20 & 17 & 20 & 14 & 23 & 21 & 17 \\
\hline 22 & 17 & 18 & 19 & 18 & 25 & 20 & 19 \\
\hline 21 & 15 & 20 & 18 & 20 & 20 & 18 & 13 \\
\hline 19 & 18 & 15 & 15 & 18 & 23 & 22 & 20 \\
\hline 18 & 16 & 10 & 16 & 14 & 18 & 20 & 18 \\
\hline 17 & 14 & 10 & 13 & 13 & 15 & 14 & 17 \\
\hline 15 & & & & & & & \\
\hline
\end{tabular}

Berdasarkan posisi 64 lokasi pada Tabel 3.1, ditentukan semivariogram eksperimental yang bersifat isotropik, dan diperoleh model semivariogram linear dengan slope 3 dan nugget efect 3 (Amstrong [1]). Model semivariogram tersebut selanjutnya diterapkan untuk menentukan bobot spasial pada STAR(1,1). Seperti hanlnya bobot seragam dan bobot seperjarak kuadrat, maka untuk studi kasus penerapan matriks bobot spasial dipilih 4 posisi lokasi, koordinat lokasi dan nilai realisasi dari variabel acak berdasarkan Tabel 3.1, dan diperoleh:

Tabel 3.2 Posisi Lokasi, Koordinat dan $Z(t)$

\begin{tabular}{|c|c|c|}
\hline Lokasi & Koordinat & $Z(\mathrm{t})$ \\
\hline $\mathrm{s}_{1}$ & $(0,8)$ & 26 \\
\hline $\mathrm{s}_{2}$ & $(8,8)$ & 14 \\
\hline $\mathrm{s}_{3}$ & $(0,0)$ & 15 \\
\hline $\mathrm{s}_{4}$ & $8,0)$ & 11 \\
\hline
\end{tabular}


Dengan menggunakan persamaan (3.6), (3.7), (3.8) dan posisi lokasi sesuai Tabel 3.2 diperoleh matriks bobot spasial yang distandarisasi sebagai berikut:

$$
\mathrm{W}_{\mathrm{S}}\left(h_{i j}\right)=\left(\begin{array}{cccc}
0 & 0,3650 & 0,3650 & 0,2699 \\
0,3650 & 0 & 0,2699 & 0,3650 \\
0,3650 & 0,2699 & 0 & 0,3650 \\
0,2699 & 0,3650 & 0,35650 & 0
\end{array}\right)
$$

\section{Penerapan Matriks Bobot Model STAR(1;1)}

Dengan menggunakan S-Plus 2000, dibangkitkan galat yang berdistribusi normal $N(0,1)$ dengan 50 pengamatan untuk 4 lokasi. Selanjutnya dipilih nilai parameter $\phi_{10}=0,3$ dan $\phi_{11}=0,5$, sehingga didapat model $\operatorname{STAR}(1 ; 1)$.

$$
\grave{Z}(t)=0,3 Z(t-1)+0,5 W Z(t-1)+e(t)
$$

Model simulasi STAR(1;1) pada persamaan (4.1) digunakan untuk memperoleh data simulasi dari 4 lokasi dengan 50 pengamatan.

\subsection{Penerapan Matriks Bobot Seragam}

Matriks bobot seragam pada persamaan (3.2) digunakan pada data simulasi, bobot seragam tersebut adalah:

$$
\mathrm{W}=\left(\begin{array}{cccc}
0 & 0,5 & 0,5 & 0 \\
0,5 & 0 & 0 & 0,5 \\
0,5 & 0 & 0 & 0,5 \\
0 & 0,5 & 0,5 & 0
\end{array}\right)
$$

Matriks bobot yang diperoleh disubstitusi ke persamaan (4.1), sehingga diperoleh data simulasi model STAR $(1,1)$ untuk 4 lokasi. Selanjutnya dilakukan penaksiran parameter dengan metode kuadrat terkecil menggunakan S-Plus 2000, diperoleh nilai taksiran parameter $\phi_{10}=0,4566$ dan $\phi_{11}=0,4230$ dan menghasilkan taksiran model STAR(1,1) sebagai berikut

$$
\overrightarrow{\hat{Z}}(t)=0,4566 \vec{Z}(t-1)+0,4230 \mathrm{~W} \vec{Z}(t-1)
$$

Model STAR $(1 ; 1)$ ini sudah stasioner dilihat dari taksiran parameter yang diperoleh, yaitu: $\phi_{10}=0,4566$ dan $\phi_{11}=0,4230$ dan memenuhi syarat stasioner model STAR(1,1), yaitu $\left|\phi_{10}+\phi_{11}\right|<1$ (Ruchjana[3]). Dengan memasukkan nilai matriks bobot seragam, model STAR $(1,1)$ menjadi:

$$
\overrightarrow{\hat{Z}}(t)=0,4566 \vec{Z}(t-1)+0,4230\left(\begin{array}{cccc}
0 & 0,5 & 0,5 & 0 \\
0,5 & 0 & 0 & 0,5 \\
0,5 & 0 & 0 & 0,5 \\
0 & 0,5 & 0,5 & 0
\end{array}\right) \vec{Z}(t-1)
$$

Model STAR (1;1) pada persamaan (4.3) dengan matriks bobot seragam digunakan untuk checking diagnostic dan diperoleh taksiran peengamatan dan taksiran galat serta jumlah kuadrat galat dari model sebesar190,6. 


\subsection{Penerapan Matriks Bobot Seperjarak Kuadrat}

Matriks bobot seperjarak kuadrat sesuai persamaan (3.5) adalah:

$$
\mathrm{W}=\left(\begin{array}{cccc}
0 & 0,4 & 0,4 & 0,2 \\
0,4 & 0 & 0,2 & 0,4 \\
0,4 & 0,2 & 0 & 0,4 \\
0,2 & 0,4 & 0,4 & 0
\end{array}\right)
$$

Matriks bobot yang diperoleh disubtitusi ke persamaan (4.1) sehingga didapatkan data simulasi model STAR(1,1) dengan matriks bobot seperjarak kuadrat. Kemudian dilakukan penaksiran parameter dengan metode kuadrat terkecil menggunakan S-Plus 2000, diperoleh nilai taksiran parameter $\phi_{10}=$ 0,3712 dan $\phi_{11}=0,5001$, sehingga taksiran model $\operatorname{STAR}(1,1)$ didapat sebagai berikut:

$$
\begin{aligned}
& \overrightarrow{\hat{Z}}(t)=0,3712 \vec{Z}(t-1)+0,5001 \mathrm{~W} \vec{Z}(t-1) \\
& \hat{\mathbf{Z}}(t)=0,3712 \hat{\mathbf{Z}}(t-1)+0,5001\left(\begin{array}{cccc}
0 & 0,4 & 0,4 & 0,2 \\
0,4 & 0 & 0,2 & 0,4 \\
0,4 & 0,2 & 0 & 0,4 \\
0,2 & 0,4 & 0,4 & 0
\end{array}\right) \hat{\mathbf{Z}}(t-1)
\end{aligned}
$$

Model STAR $(1 ; 1)$ seperti yang ditunjukkan pada persamaan $(4.4)$ yang sudah lengkap dengan matriks bobotnya digunakan untuk checking diagnostic dan memperoleh data taksiran dan galat taksiran. Nilai jumlah kuadrat galat model STAR(1,1) dengan matriks bobot seperjarak kuadrat adalah 189,062.

\subsection{Penerapan Matriks Bobot spasial}

Matriks bobot spasial sesuap persamaan (3.10) adalah:

$$
\mathrm{W}=\left(\begin{array}{cccc}
0 & 0,3650 & 0,3650 & 0,2699 \\
0,3650 & 0 & 0,2699 & 0,3650 \\
0,3650 & 0,2699 & 0 & 0,3650 \\
0,2699 & 0,3650 & 0,3650 & 0
\end{array}\right)
$$

Matriks bobot yang diperoleh disubtitusi ke persamaan (4.1) sehingga didapatkan data simulas model STAR91,1) dengan bobot spasial. Selanjutnya dilakukan penaksiran parameter dengan metode kuadrat terkecil menggunakan S-Plus 2000, diperoleh nilai taksiran parameter $\phi_{10}=0,3992$ dan $\phi_{11}=0,4683$, dengan taksiran model $\operatorname{STAR}(1,1)$ sebagai berikut

$$
\begin{aligned}
& \hat{\hat{Z}}(t)=0,3992 \hat{Z}(t-1)+0,4683 \mathbf{W} \hat{Z}(t-1) \\
& \overrightarrow{\hat{Z}}(t)=0,3992 \hat{Z}(t-1)+0,4683\left(\begin{array}{cccc}
0 & 0,3650 & 0,3650 & 0,2699 \\
0,3650 & 0 & 0,2669 & 0,3650 \\
0,3650 & 0,2699 & 0 & 0,3650 \\
0,2699 & 0,3650 & 0,3650 & 0
\end{array}\right) \hat{Z}(t-1)
\end{aligned}
$$


Model STAR (1;1) seperti yang ditunjukkan pada persamaan (4.5) yang sudah lengkap dengan matriks bobot spasial digunakan untuk memperoleh simulasi data pengamatan dan taksiran galat. Jumlah kuadrat galatnya adalah sebesar 187.7512 .

Pada Gambar 4.1, 4.2 dan 4.3 ditampilkan histogram galat 4 lokasi pengamatan untuk masing-masing matriks bobot. Histogram taksiran galat model STAR(1,1) pada 4 lokasi dengan matriks bobot seragam, bobot seperjarak kuadrat dan bobot spasial belum sepenuhnya menunjukkan pendekatan ke distribusi normal, namun demikian ketiga model STAR $(1,1)$ memenuhi syarta stasioner, dan model $\operatorname{STAR}(1,1)$ dengan matriks bobot spasial dalam contoh ini memberikan jumlah kuadrat galat yang minimum, sehingga bobot spasial memberikan model $\operatorname{STAR}(1,1)$ yang terbaik dibandingkan model STAR(1,1) dengan matriks bobot seragam dan bobot seperjarak kuadrat.
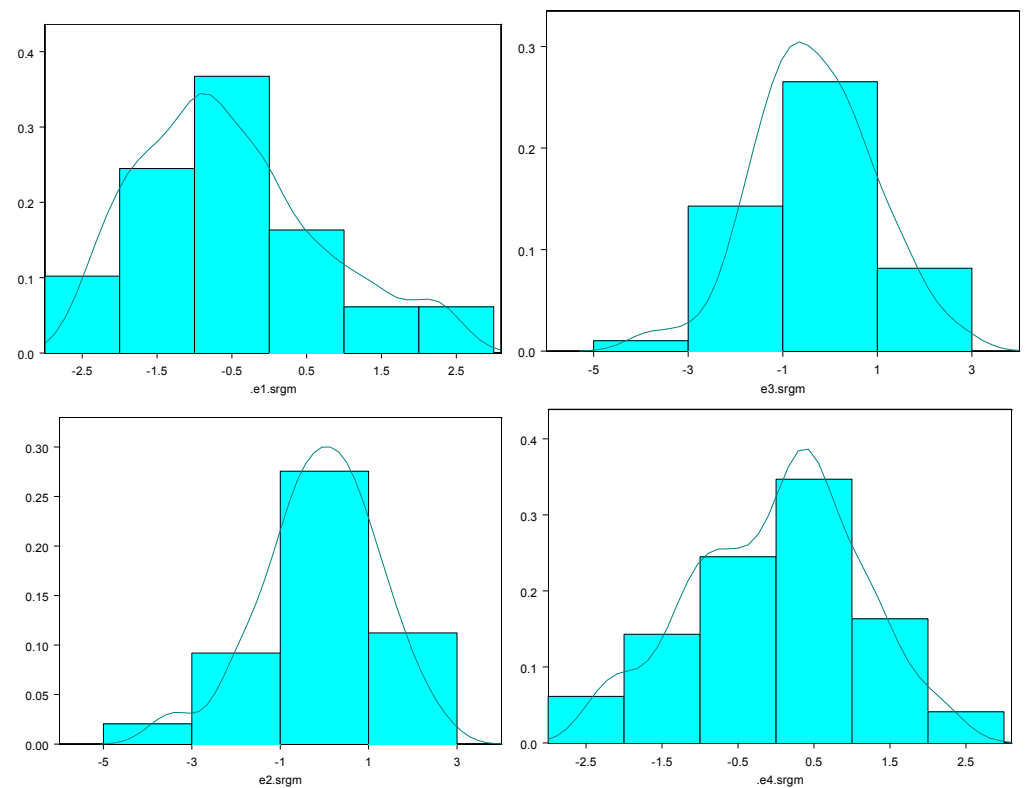

Gambar 4.1. Histogram Galat dengan Matriks Bobot Seragam

Perbandingan ketiga hasl simulasi data model $\operatorname{STAR}(1,1)$ dengan matriks bobot yang berbeda disajikan pada Tabel 4.1. Pada Tabel 4.1 terlihat bahwa jumlah kuadrat galat yang dihasilkan oleh model $\operatorname{STAR}(1,1)$ dengan bobot spasial lebih kecil bila dibandingkan dengan bobot seragam maupun bobot seperjarak kuadrat. Jadi untuk data simulasi ini dapat ditarik simpulan bahwa model STAR $(1,1)$ dengan bobot spasial lebih baik daripada model STAR(1,1) dengan bobot seragam maupun bobot seperjarak kuadrat, karena menghasilkan jumlah kuadrat galat yang minimum. 

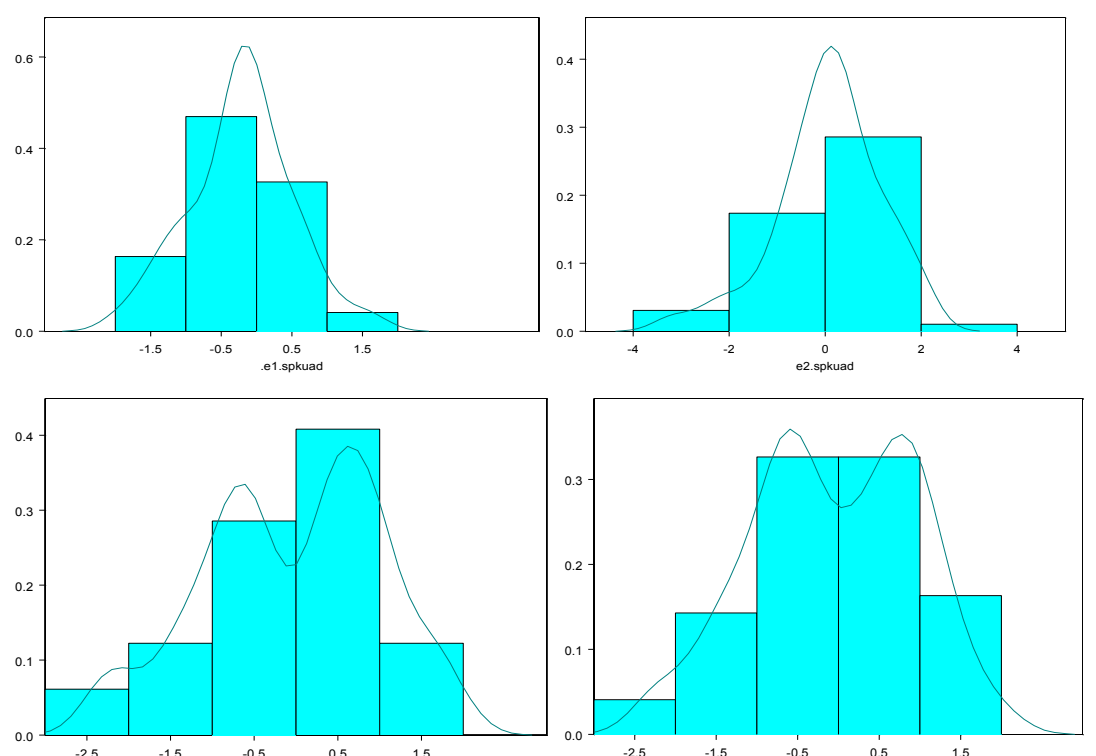

Gambar 4.2. Histogramm Galat dengan Matriks Bobot ${ }^{\text {Sepped }}$ erjarak Kuadrat
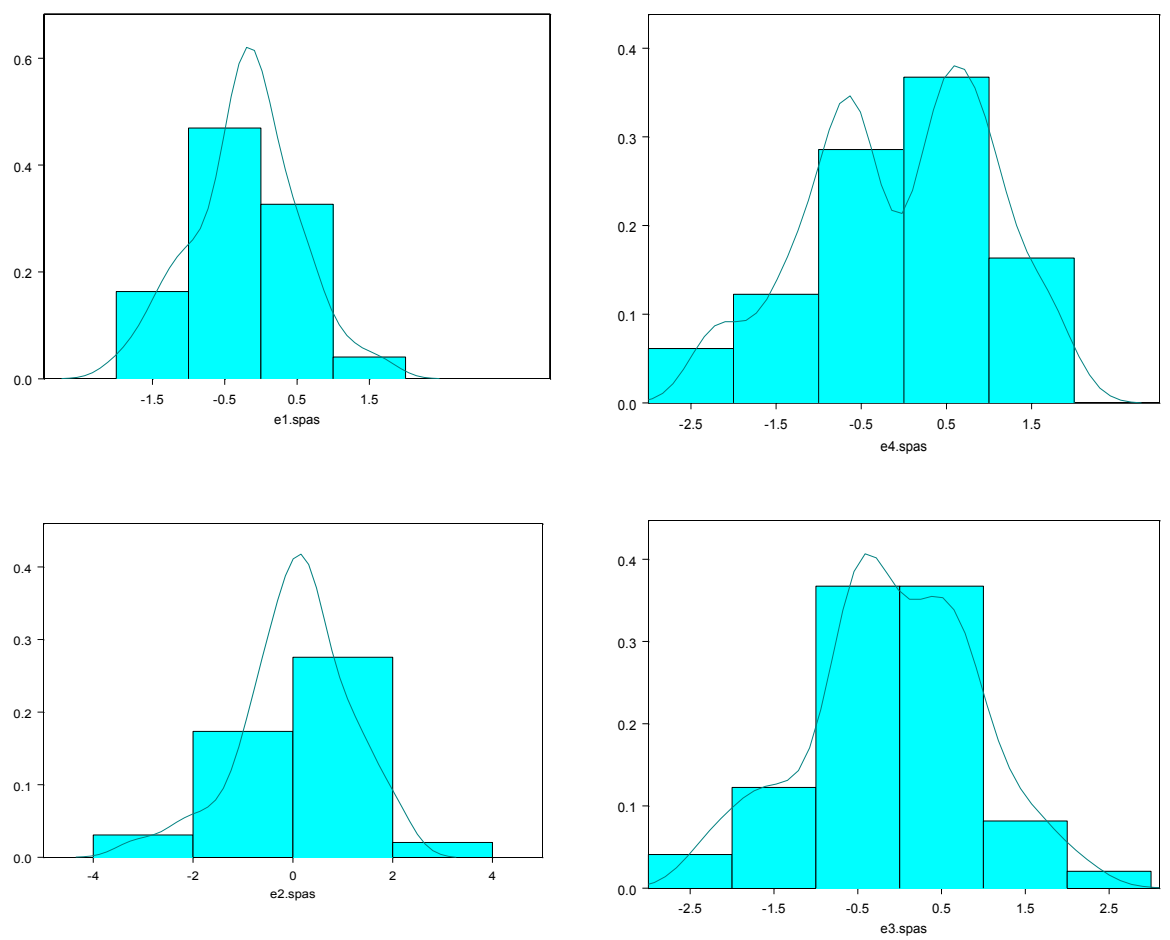

Gambar 4.3. Histogram Galat dengan Matriks Bobot Spasial 
Tabel 4.1. Parameter Simulasi, Parameter Taksiran dan JKG Model STAR(1;1) Matriks Bobot Seragam, Matriks Bobot Seperjarak Kuadrat dan Matriks Bobot Spasial untuk Data Simulasi dengan 50 Pengamatan

\begin{tabular}{|l|c|c|c|}
\hline \multicolumn{1}{|c|}{ Parameter simulasi } & \multicolumn{2}{|c|}{$\phi_{10}=0,3$} & $\phi_{11}=0,5$ \\
\hline \multicolumn{1}{|c|}{ Matriks bobot } & $\phi_{10}$ & $\phi_{11}$ & JKG \\
\hline & & & \\
Seragam & 0,4566 & 0,4230 & 190,6115 \\
Seperjarak kuadrat & 0,3712 & 0,5001 & 189,0623 \\
Spasial & 0,3992 & 0,4683 & $\mathbf{1 8 7 , 7 5 1 2}$ \\
\hline
\end{tabular}

\section{Simpulan}

Berdasarkan uraian pada bab-bab sebelumnya, dapat diambil simpulan bahwa Model STAR(1;1) merupakan pengembangan dari model AR(1) secara simultan di beberapa lokasi dipengaruhi oleh bobot antar lokasi yang dipilih. Model STAR(1;1) pada data simulasi 4 lokasi dengan matriks bobot spasial lebih baik daripada model STAR(1;1) dengan matriks bobot seragam maupun dengan matriks bobot seperjarak kuadrat, karena memiliki jumlah kuadrat galat yang minimum.

\section{Daftar Pustaka}

1. Armstrong, M., 1998., Basic Linear Geostatistics., Springer-Verlag Berlin Heidelberg New York

2. Cryer, J. D., 1986., Time Series Analysis. USA:PWS-KENT Publising Company.

3. Ruchjana, B.N, 2002., Suatu Model Generalisasi Deret waktu Autoregrsi dan Penerapannya pada Produksi Minyak Bumi. Disertasi tidak diterbitkan. Bandung: Program Pascasarjana Institut Teknologi Bandung.

4. Purcell, E.J. dan D. Varberg (Alih bhs: I. Susila)., 2003., Kalkulus dan Geometri Analitik. Jilid 1, Erlangga.

5. Pfeifer, P.E., Deutsch, S.J., 1980., A three-stage iterative procedure for space-time modeling. Technometrics, vol. 22, pp. 397-408. 